\title{
Property titling and conveyancing
}

\author{
Chapter 12 in Kenneth Ayotte and Henry E. Smith, eds., Research \\ Handbook on the Economics of Property Law, Research Handbooks in \\ Law and Economics Series (Series editors: Richard Posner and Francesco \\ Parisi), Edward Elgar, Cheltenham UK, 2011, pp. 237-56.
}

\section{By Benito Arruñada*}

This chapter analyzes titling institutions and the regulation of supporting conveyancing services. After examining the tradeoff of enforcement benefits and consent costs posed by property rights, it explains how different public titling systems (privacy, recording and registration) try to solve this tradeoff, and what the consequences are for the nature and regulation of private conveyancing services. The chapter ends with a discussion of some empirical issues and data which are useful for comparing, designing and managing titling and conveyancing systems.

Keywords: property rights, enforcement, transaction costs, registries, lawyers, notaries.

JEL: D23, K11, K12, L85, Q15.

\footnotetext{
* Pompeu Fabra University and Barcelona GSE. E-mail: benito.arrunada@upf.edu. I thank Kenneth Ayotte, Manuel Bagüés, Henry E. Smith and Giorgio Zanarone for very helpful comments. Usual disclaimers apply. This work received support from the European Commission through the Integrated Project CIT3-513420 and the Spanish Ministry of Science and Innovation, through grant ECO2008-01116.
} 


\section{Enforcement benefits vs. 'consent' costs}

Rights to land and many other assets can be enforced as property rights, iura in rem, claimable against the asset itself and therefore valid against all persons, erga omnes. ${ }^{1}$ These property rights are said to 'run with the land,' meaning that they survive unaltered through all kinds of transactions and transformations dealing with other rights on the same parcel of land or on a neighboring parcel. For example, the mortgagee keeps the same claim on the land even after the mortgagor sells it. Property rights oblige all people: the new owner who has purchased the land is obliged to respect both the mortgage and, in particular, the right to foreclose in case the guaranteed debt is not paid. Enforcement of a property right is independent of who holds other rights on the same asset. Alternatively, rights on assets can be contract rights, enforceable against a specific person, inter partes. To clarify the difference between property and contract rights, consider what happens in the case of a lease of land, this being a right that in many jurisdictions may be structured as either a contractual or a property right. Assume that the land is sold during the life of the lease. If the lease is a contract right, the lessee loses the right of occupation, and gains instead a contract right against the lessor. However, if the lease is a property right, the lessee keeps the right of occupation. It is then the land purchaser who may have a contract right against the seller, if the sale was made free of leases. The buyer is subrogated into the seller's position. There is

\footnotetext{
${ }^{1}$ The analysis in sections I and II draws on the material presented in Arruñada (2003).
} 
no change to the lease, which has run with the land from the seller to the buyer, surviving intact after the sale.

When the law enforces a right as a right in rem, consent of the right holder is required for the right to be affected, that is, damaged, in any way. This requirement of consenteither real or constructive-provides precious enforcement benefits for rights on durable and immovable assets. On the other hand, the enforcement of contract rights depends on the availability, resources and legal status of persons, who are mobile and may become unavailable or judgment proof when obliged to pay. For durable assets, a property right is therefore much more valuable than a contract right having the same content- that is, when the only difference between them is that the latter lacks in rem enforceability.

These enforcement benefits come at a cost, however. When multiple rights exist on an asset, transactions do not convey property rights with the promised in rem extent until all affected right holders have consented. In other words, to produce perfect property — that is, in rem_rights, some kind of explicit or implicit contracting has to take place between the transactors and each of the affected right holders, in order for the latter to give their consent. Many institutions in the field of property law are designed to make these 'contracts' with affected right holders possible. Consent can be given explicitly, by private agreement, declaring to a register or in court proceedings, as well as implicitly, by the simple passing of time. Consent can also be produced at the moment the relevant transaction takes place. Consequently, the rights resulting from the transaction will be free of uncertainty as to whom the true legal right holder is and as to their precise nature. Alternatively, consent can be postponed, and the relevant transaction then produces rights which are burdened with the survival of any property rights whose right holders have not yet consented. 
In any case, without the consent of affected right holders, transactions produce a mix of property and contract rights: property — in rem-effects to the extent compatible with the surviving property rights held by others, and contract rights for the difference. The proportion of property and contract rights in the mix varies with the kind of conflicting right. In the extreme case of a fraudulent conveyance, the grantee gets only a contract right against the grantor, who is not the true legal owner. More generally, any intended property right is in fact partially contractual if an affected right holder keeps a contradictory or concurrent right against it.

Property rights thus face a tradeoff with positive and negative effects. On the one hand, they facilitate specialization by ensuring enforcement, given that right holders' consent is required to affect them. However, for the same reason, their survival after conveyance of the asset or any other transformation of rights requires costly institutions and resources in order to organize the process of searching, bargaining and contracting for consent. In particular, the possibility of hidden property rights increases the information asymmetry between the conveying parties: the seller knows better than the acquirer about hidden property rights. More generally, the need of knowing which conflicting property rights exist, finding out who their right holders are, bargaining with such right holders to obtain their consent and contracting or somehow formalizing an agreement with them, all increase the costs of transforming and conveying rights. This may in turn hamper investment, trade and specialization. $^{2}$

2 The tradeoff is between the strength of one's rights and their transferability at low cost. The tradeoff is more or less explicit in, among many others, Baird and Jackson (1984), Epstein (1987), Levmore (1987) and Rose (1988), as well as in more recent works which have mostly focused on the role of the numerus clausus of property rights, such as Heller 


\section{Titling systems}

\section{A. Privacy of rights as a benchmark}

Under the Roman Law tradition of private conveyance that was dominant in Europe until the 19th century, private contracts on land had in rem effects on third parties even if they were kept secret. In cases of conflict, courts 'established title' (that is, they allocated property and contract rights) on the basis of evidence on possession and past transactions, whether or not these transactions had remained hidden. This potential enforcement of adverse hidden rights made full consent impossible to reach ex ante, hindering trade and specialization. All transactions in land then gave rise, totally or partially, to contract rights and the enforcement advantage of property rights remained unfulfilled, especially with respect to abstract rights, such as mortgages.

Whatever the palliatives being applied (mainly, reliance on possession and the chain of title deeds), the costs of contracting property rights under a regime of pure privacy are such that modern systems of property law have abandoned privacy. At a minimum, the law requires the publicity of contracts as a prerequisite for them to attain in rem effects-i.e. to convey property rights and not mere contract rights. If they keep their rights private, right holders lose or risk losing in rem effects. Private contracts may create obligations among the

(1999), Merrill and Smith (2000), and Hansmann and Kraakman (2002). A version of the tradeoff is also present in the classic work by Calabresi and Melamed (1972). Our analysis, however, focuses on a three-party sequence of two transactions instead of a taking affecting two parties. Moreover, Calabresi and Melamed's property rule is weaker, referring only to 
parties but do not bind third parties—all other right holders and, especially, potential future buyers and lenders. Publicity therefore facilitates the search for which property rights are alive, making it possible to reach consent ex ante, purging titles, and reducing information asymmetries between the parties.

\section{B. Recording of deeds}

Legal systems vary substantially, however, with respect to how and when any contradiction with other property rights must be purged by obtaining the consent of the holders of these affected rights. The two paradigms are recorders of deeds and registers of rights.

Recorders of deeds are still used in most of the US, France and some other countries, many of which have a French legal background. They enroll and keep private transaction documents ('title deeds') and thus provide evidence on property claims. This evidence is used by the courts to allocate property rights ex post—after litigation. In practice, the system is effective if courts apply a non-standard priority rule and, when deciding on a conflict with third parties, they determine the priority of claims from the date of recording in the public office and not from the date of the deed. This priority rule effectively motivates parties to record from fear of losing title through, for example, a wrongful second 'double sale' to an innocent acquirer. If such a second sale were recorded first, it would gain priority over the

the ability to force a would-be taker to bargain for a consensual transfer, and thus arguably has little to do with a right in rem. 
first one. ${ }^{3}$ Consequently, all relevant evidence on property rights is publicly available by inspecting both the public records and the land itself. ${ }^{4}$ From the point of view of third parties, the record, in principle, is complete. Some other claims may not be recorded and may well be binding for the parties conveying them, but these hidden claims have no effect on third parties (more precisely, on bona fide acquirers for value).

This inclusiveness of the record makes it possible to produce information on the quality of title ('title reports') by having different experts examine all relevant deeds, which are only those that have been recorded. ${ }^{5}$ These experts form an industry which, despite adopting different forms in each country (mainly, that of notaries public in countries such as France, and abstractors, attorneys, title insurance agents and title insurance underwriters in the US6), performs similar functions in all of them as it (1) reduces information asymmetry between the parties, (2) reallocates risk from the acquirer to the expert, and (3) makes it possible to clean title clouds by obtaining the consent of the affected third parties. If these clouds are not removed, the grantee will not transact or will insist on modifying the transaction, reducing the price or including additional warranties, in compensation for the survival of property rights that are contradictory to those that were contracted.

${ }^{3}$ In most jurisdictions, this priority-of-recording rule applies only to innocent or good faith acquirers, and judges infer that such good faith is lacking when the acquirer knew (had "notice") of the previous transactions. See, for instance, Merrill and Smith (2007: 919-23) for the four different systems being applied in different parts of the US.

${ }^{4}$ In most jurisdictions, it is necessary to inspect the land to find out about physical possession. On the role played by possession in the transfer of property rights in different kinds of assets, see Baird and Jackson (1984).

${ }^{5}$ Statutory law usually limits the time required for title searches, making it unnecessary to examine the whole chain of titles. For example, 30 states in the US have marketable title acts setting periods of between 30 and 75 years (Boackle, 1997).

${ }^{6}$ Arruñada (2002) compares the role of title insurance under recording and registration. 
Despite private incentives to purge rights ex ante, the public record may, however, contain evidence on potentially contradictory rights. The recording office is obliged by law to accept all deeds respecting certain formal requirements (mainly, the date of the contract and the names of the parties), whatever their legality and their collision with preexisting property rights. It will therefore contain potentially three kinds of deed: (1) those resulting from transactions made without previous examination; (2) those granted after an examination but without having all defects removed; and (3) those that define purged and non-contradictory property rights. Experts examining the title of a parcel do not know a priori which of these kinds of deed are recorded concerning it. For each transaction, they will therefore examine all relevant deeds dealing with that parcel in the past.

\section{Registration of rights}

Registers of rights such as those in Australia, Germany, England or Spain go one step further: instead of merely providing information on claims, they define the rights. They thus require a previous, complete purge of property claims. As in deed recording, private contracts gain priority when they are first lodged to the register. They are then subject, however, to substantive review by the registrar, in order to detect any potential conflict which might damage other property rights. Rights are registered (antedating the effects of registration to the filing date ${ }^{7}$ ) only when the registrar determines that they do not affect any other property right, or the holders of affected rights have consented. Otherwise, registration is denied and the parties have to restructure their contract or obtain the relevant consents. 
Information on the register is simplified in parallel with the purge of rights. Rights defined in each new contract are registered together with all surviving rights on the same parcel of land. Extinguished rights are removed or deleted, however, which makes access to the register very simple. Effective identification of each parcel of land is necessary for the system to work, as is the use of a tract index to locate all rights in each parcel.

Given that any contradictions are purged ex ante, the register is able to provide 'conclusive,' 'indefeasible’ title, meaning that a good faith third party for value acquires a property right if the purchase is based on the information provided by the register. If the seller's right is later shown to be defective, the buyer keeps the property right and the original owner gets contract rights against the seller and the register. The property right is allocated in these exceptional cases to the acquirer, but this happens only when there has been a failure in the register. ${ }^{8}$ No contradiction should appear in most cases, however, so property enforcement is based on right-holders’ consent. Registration thus interferes with private property much less than is often claimed, as its intervention focuses on the timing and the completeness of the private purging of rights. Registration is regulated by registrars or judges but ultimate decisions are made by right holders by giving consent. Privacy and recording allow parties more discretion on the timing and heavier reliance on privately produced information. Rights therefore seem to be more the product of private decisions, but this perception is deceptive because even recorded rights retain a higher contractual content, given the survival of conflicting claims in rem. Additional public intervention by

${ }^{7}$ A register of rights can thus be seen as a double register: it is both a temporary record of deeds (the 'presentment' book that dates titles) and a definitive register of rights. 
the court is required to transform them into property rights at an in rem level equivalent to that provided by registration. Furthermore, this additional judgment is also subject to the possibility of allocation failure.

\section{The role of conveyancing services in each titling system}

All three public titling systems share functional similarities: all three are based on enforcing individual consent as a requirement. As a consequence, contracting proceeds in two steps: first, parties agree to the transaction; second, they gather the consent of affected right holders. By making this gathering of consent more or less difficult, the three titling systems induce different demands for private 'conveyancing services', these being understood as services provided by notaries, lawyers or other professionals that support contracting between the parties. ${ }^{9}$

\section{A. Conveyancing under privacy}

Under privacy, property rights would eventually be enforced in rem even if the transaction remained hidden. By themselves, private contracts could not damage third

\footnotetext{
${ }^{8}$ Because registration failure reduces enforcement of pre-existing rights, there must necessarily be few of such failures. Otherwise, registration would not survive, due to the pressure and desertion of owners.

${ }^{9}$ Section III is largely based on Arruñada (2007b). In addition to analyzing how changes in titling institutions affect the demand for conveyancing, the article analyzes parallel changes in the markets, such as the emergence of large and reputable parties, the tendency to use standardized transactions, and the appearance of electronic notarization.
} 
parties: the baseline principle nemo dat quod non habet (no one can deliver what one does not have) fully applies. For instance, if $B_{2}$ is purchasing land from $O, B_{2}$ should be worried that $O$ might have previously sold the land to $B_{1}$ or mortgaged the same land to $L$. However, $B_{1}$ is fully protected because, assuming neither of the two buyers took possession, the courts will establish title according to the date of the contract and give the land to $B_{1}$, with $B_{2}$ having only a contractual claim on $O$. Buyer $B_{1}$ should be worried, however, about the possibility that $O$ and $B_{2}$ may fraudulently antedate their contract.

This system maximizes the complexity of conveyancing services. It first generates demand for lawyers to design and evaluate title guarantees offered by sellers and third parties which, even if they do not protect buyers in rem, at least provide some protection in personam. Second, reducing transaction costs when rights are embodied in titles also requires protecting the titles against fraud. ${ }^{10}$ From early times, legal systems required the presence of witnesses, surely the simplest solution, often qualified in terms of number, age, expertise and authority. In addition, titles are protected by requiring that specialists (lawyers or notaries) are involved in producing them. A common solution making fraud difficult is for grantees and mortgagees to demand delivery of the full chain of titles from grantors and mortgagors, so that the risk of previous competing transactions is reduced and later transactions would require faking a full chain of titles. In a sense, the chain of titles is used as a private record but without any guarantee that it is exhaustive.

10 The pervasiveness of compulsory proof and the ingenuity applied to developing it attest to the importance of restraining fraudulent conveyance. For historical references, see Arruñada (2003: 407). 
The role of conveyancers is greatest under this privacy system, because they act as both producers and depositories of the main body of evidence used to establish title. In this context, reducing competition between professionals may serve two purposes.

First, sharing information on their contracts among conveyancers will substantially save on the costs of structuring new deals and make them more secure. This process could be observed recently in Andorra, a small country between France and Spain, which still applies a relatively pure system of Roman Law, including privacy for real estate transactions. The few Andorran notaries started to share information on mortgages after a new regulation was enacted in 1998.11

Second, reducing competition will lessen the incentives of conveyancers to cheat each other, and may provide some support for the protection of third parties against fraud. The system hinges, however, on conveyancers dating deeds faithfully. For instance, notaries chronologically enter all documents into the notary's protocol, which provides an additional safeguard on the dating of documents. But the system may be prone to fraud as can be seen in some Latin American countries where, given the sorry state of their land registers, judges tend to refer to the date of deeds, falling back de facto into a privacy system and thus increasing the motivation to fraudulently antedate deed notarization, apparently a common occurrence (Arruñada, in press).

11 Section 12 of the Andorran 1996 Notary Act (Llei del notariat 28-11-1996, BOPA, 27 December 1996) and Temporary Rule 2 of the Andorran 1998 Notary Regulation (Reglament general del notariat 20-2-1998, BOPA, 25 February 1998). 


\section{B. Conveyancing under recording}

Under recording, private contracts and other documents are filed in a public office that only sets the filing date and reviews the formalities required to index it. The need to safeguard the contract is limited compared to privacy because recording avoids a typical fraud under privacy—antedating a sale or a mortgage. The role of conveyancers as depositories of documents also becomes less relevant and tends to disappear. Something similar happens to the demand for writing sophisticated title guarantees, to the extent that the filing system makes them superfluous.

Conversely, recording does not avoid the risk of a double sale or mortgage. In the previous example, the recording office will not object to recording the second sale by $O$ to $B_{2}$, even if the first sale to $B_{1}$ is already on record. Nor will it object to recording a sale to $B_{2}$ free of charges even if a mortgage of the land to $L$ has previously been recorded. Buyers will therefore be aware that the apparent owner might have sold or mortgaged beforehand, and this deed might have been recorded and gained priority.

Furthermore, finding the relevant information in the public record is not easy, because it contains a mix of relevant and irrelevant deeds resulting from all the previous transactions, and the deeds are often indexed on a personal basis, using name or grantor-grantee indexes. To avoid nasty surprises and receive a report on the quality of title, parties will retain some sort of title agent to search the record fully and detect any previous sales or other title cloud. Consequently, the role of these title agents in searching and reporting on the quality of title remains important, creating a substantial demand for conveyancers. 
However, the better the organization of the recording office, the less important the function of title agents. Two innovations with respect to pure recording as described above are crucial: monitoring by the recording office that the grantor figures on record as right holder of the right being conveyed and use of a tract index, both of which have been applied, for example, in France since 1955 (règle de l'effet relatif and fichier immobilier) but not in most of the US. ${ }^{12}$ First, the quality of the recorded information improves substantially when the recording office requires that only those already recorded as right holders can be grantors in a new transaction, thus eliminating the risk of double sales. Similarly, a well-functioning recording office will require the lender's consent before canceling a mortgage. Second, the use of tract indexes, instead of relying on personal indexes of grantors and grantees, is essential for avoiding filing errors. When the records are poorly organized (as in many US counties), it seems natural to develop private 'title plants,' that is, well-organized replicas of the public records. The investment required to build such plants will move the comparative advantage from individual title agents to the operators of the plants, who then play the leading role in the whole process.

\section{Conveyancing under registration}

Under registration, the register not only establishes the date but also performs a substantive review of the transaction, impeding any potential collision with property rights held by third parties. This drastically diminishes the demand for high-value services in the

12 See, for instance, Piedelièvre (2000: mainly 12-13 and 50-55) and Simler and Delebecque (2000: 659-62 and 670-74), about the situation in France, and Dukeminier and Krier (1998: 653-57) about the US. 
preparation of the private contract. There is no role for title guarantees, and the register itself performs the title search and produces a title certificate.

Moreover, under registration, an innocent purchaser who relied on the register keeps the land to the detriment of the original owner. This switch in the adjudication rule drastically changes the incentives of lawyers and notaries. They are no longer indirectly motivated by the interest of their clients to identify and avoid potential title defects, as they were under privacy and recording. Rather, they become the advocates of the parties to the register, which is now the only instance protecting the interest of third parties, whose property rights would turn into contract rights in case of registration error. In other words, given that under registration courts adjudicate conflicting rights to innocent acquirers, parties tend to encourage conveyancers and title examiners to disguise the facts before the register instead of preventing such title conflicts, a change that further reduces the former gatekeeping function of these professionals.

Understandably, the demand for conveyancers to authenticate contracts also diminishes, for several reasons. First, registers are well placed to authenticate documents by themselves. In contrast to mere recording offices, registers perform a highly technical task when testing the legality of private contracts. The knowledge and safeguards necessary to perform such a task can easily be applied to a relatively less technical task such as authentication. This is shown empirically by the existence and effectiveness of registers of rights in Scandinavian countries, which require neither notarized deeds nor intervention by lawyers but simply rely on witnesses. Second, banks are now the real experts at identifying individuals, and this also diminishes the role of lawyers and notaries in contracts to which banks are parties. Third, the development of digital authentication (often called electronic notarization) allows 
parties to disintermediate the notary and dispense with witnesses for authenticating

purposes. This may even be more effective than traditional methods, now that urban lawyers and notaries do not personally know most of the parties, as they did in the past, and have to rely on indirect proof such as ID cards. Finally, such lack of personal knowledge also destroys professionals’ ability to evaluate the parties’ mental capacity.

Nor is it necessary for lawyers to be involved in the start-up stages of a registration system. Given that start-up costs are high, if a reliable supply of party-independent (and, therefore, monopolistic) conveyancing services is available, a way of saving on start-up costs could be to make use of conveyancers to purge titles and improve the quality of deeds. ${ }^{13}$ However, provisional registration of possessory rights provides an alternative, cheaper and probably more effective solution. Furthermore, reliance on conveyancers for the start-up stage poses the risk that this mandatory intervention may extend beyond their useful life, as a functional, steady-state register clears titles on registered land effectively and at low cost without such intervention.

This shrinking of conveyancing under registration helps to explain why conveyancers tend to oppose registration. Indeed, conveyancers have often managed to impede the development of registers, monopolizing entry into existing registers or debasing their legal effects — for instance, by reinforcing the effects of possession or title deeds against those of

13 As claimed by solicitors in the transition between titling systems in Ontario, Canada, where the conversion of deed recording (there called 'Registry' system) into a register of rights ('Land Titles') is claimed to have been made possible by the cumulative work of lawyers in examining and purging titles (Troister and Waters, 1996). 
the register. ${ }^{14}$ Partly as a consequence of this, many real systems are hybrids in transition. In particular, registration systems are often plagued by the presence of 'overriding interests': rights which are enforced in rem despite not being registered (for instance, due taxes and possessory rights) or rights filed in separate administrative registers (as typically happens with municipalities’ zoning and preemption rights). This implies that in many countries the role of conveyancers is also a hybrid one, with them playing a greater role with respect to unregistered rights. For example, French notaries play a preventive role, similar to that of US title insurers with respect to the preemption rights held by tenants and municipalities (Willman and Pillebout, 2002), but very different with respect to ownership rights, because the French recording office checks that the grantor's title is on record, in application of the règle de l'effet relatif.

\section{How to regulate conveyancing}

The private and social value of legal assistance in conveyancing services has therefore been declining. Regulation should be adapted accordingly, as both the information asymmetry and externality rationales for restrictive regulation hold less and less water over time, as a consequence of market and institutional changes. Moreover, regulation should be consistent with the reduced functions required of professionals. In particular, restrictive

\footnotetext{
14 For example, it has been argued that one of the reasons why Torrens registration failed in the US was the opposition of lawyers, abstracters and title insurers (for example, Bostick, 1987: 64, n. 23, citing Quintin Johnstone; Dukeminier and Krier, 1998: 721). Similarly, English solicitors stopped registration in the $19^{\text {th }}$ century (Anderson, 1992) and finally delayed its expansion for a century by requiring county votes (Bostick, 1987: 59, n. 7). Notaries' resistance to change has often also been linked to their monopoly. See, for
} 
professional licensing is less justified to the extent that comparative advantage in the provision of externalities lies now in public registers and that of overcoming information asymmetries lies with large private firms. Regulation should also be consistent in preserving or, where needed, enhancing the effectiveness of public registers.

For standard transactions, the horizon of regulation is a sort of industrialized production of property rights with low costs and no defects. This Toyota-like manufacturing of property rights requires only a few changes in countries with properly-functioning registers: simplifying overriding interests, standardizing forms and allowing digital access to the registry. In this way, standard rights in real estate would end up being contracted as commodities, ideally in a way resembling financial derivatives, with much lower transaction costs than today.

The role of law professionals in formalizing these standard transactions would be understandably small. Recent reforms and tendencies are moving in this direction, focusing the use of lawyers only on those transactions for which they are really needed. In most of the US, lawyers do not intervene in residential transactions and mortgages. In most cases, title companies, through lay employees, search the title, prepare the documents and close the transaction (Palomar, 1999). These tasks have been performed in England by licensed conveyancers since 1986. The fact that the US uses recording of deeds and England registration of rights shows that these changes are viable under both systems of public titling.

example, the cases of France in Suleiman (1987: 92-106), Belgium in Raucent (1998: 129) and Spain in Arruñada (2001). 
Liberalization does not therefore entail that lawyers and notaries quit providing conveyancing services, but does require them to focus their services on tailoring high-value transactions. They will also be needed for exceptional cases of lower value, but in these they will intervene within an organized hierarchy that filters cases, matching their complexity with the human capital of the professionals handling them. Liberalization also encourages

all sorts of providers to offer additional services, including a fuller guarantee-e.g. strict liability and no-fault errors and omissions insurance (Arruñada, 2002)—and the gathering of additional information (for instance, on the physical quality of residential real estate and zoning restrictions, which is now underprovided in many countries). Trends in countries that have been pioneers in liberalization also indicate that there will also be a good deal of vertical integration, with competition amongst organizations that combine different mixes of legal, insurance, financial, distribution and mediation services in order to both reduce conflicts of interest and provide more valuable service to end users.

\section{Empirical arguments for a comparative analysis}

The analysis in the previous two sections reached two conclusions. First, public titling is needed to overcome the difficulties of privacy in modern economies. Second, the demand for regulated private conveyancing services decreases with the development of public titling. The present section analyzes the remaining question: the choice between the two public titling systems—recording and registration. It first clarifies two of the main theoretical arguments in the old controversy about these systems—-the superiority of 
recording with respect to costs and its inferiority with respect to effectiveness, ${ }^{15}$ identifying which factors can substantially modify these theoretical comparative advantages in practice. After this analysis of the supply of titling services, attention switches to demand for them, exploring how different owners and economies demand titling of different quality, and how this may affect the social choice of titling system. Lastly, a tentative quantitative comparison is made of the performance of both titling systems

\section{A. The dubious cost advantage of recording}

Recording of deeds may enjoy an advantage over registration of rights in terms of lower costs, even when adding the additional cost of services needed for examining and assuring title quality, which are provided by lawyers, title agents, title insurers, notaries and the like. ${ }^{16}$ This advantage would stem from incentives in both the demand and the supply sides of the industry: under recording, title examination and purging are voluntary, and most supporting services are provided on the basis of private enterprise. However, registration requires ex ante purging organized by a public authority.

A main benefit of having an optional purge is that any defects not worth purging can be insured on a casualty basis either by the parties themselves or by a third party insurer. Under

15 See, for instance, the opinions along these lines of Cribbet (1975: 318), Janczyk (1977), Baird and Jackson (1984: 305) and Bostick (1987). Other authors, considering the US experience with Torrens registration, conclude that registration is costlier and less effective (Shick and Plotkin, 1978). The issues have been controversial almost everywhere. See on this, for Australia, Whalan (1982: 3-12); England, Anderson (1992); France, Picod (1999: 535); Spain, Oliver (1892); and, for the US controversy of the 1930s, Powell (1938) and McDougal and Brabner-Smith (1939). 
registration, the requirement to remove these minor defects may cause holdouts with substantial bargaining costs. ${ }^{17}$ These occurrences are probably less frequent with a stricter numerus clausus, but this may in turn be costly in terms of flexibility and specialization. ${ }^{18}$ Recording is also thought to enjoy the advantage of private incentives in the supply of title assurance and insurance services. ${ }^{19}$ Under recording, titles are examined and consents are gathered by business firms or professionals paid with a residual profit. Assuming competition, costs will tend to be minimized, including rapid innovation and adaptation to changes in technology and demand.

These cost advantages may be illusory, however, given the actual incentives of both users and suppliers. Voluntary title assurance may incur costs similar to if not higher than those of public registration because of duplicated efforts and lost economies of scope. Private organization of support services also suffers, as many of such services are natural monopolies and are heavily regulated. We will see below some empirical data which is

16 Both registration and recording can be complemented with different degrees of casualtybased title insurance. This complementarity is being shown by the introduction of title insurance in jurisdictions with registration, analyzed in Arruñada (2002).

17 This can be seen as an example of the 'anticommons' problem analyzed by Heller (1998), Heller and Eisenberg (1998) and Buchanan and Yoon (2000).

18 On the numerus clausus, see Heller (1999), who points out the role it plays in solving the so-called 'anticommons' problems; Merrill and Smith (2000), who argue that it serves to reduce the information costs in transfers of property; and Hansmann and Kraakman (2002), who emphasize the verifiability costs faced by acquirers.

19 As Dukeminier and Krier assert, "title registration puts title assurance in the hands of the government whereas the recording system puts title assurance in private hands using the public records" (1998: 721). This might allow recording to produce better information on title quality, supposedly overcoming its information difficulties, as "the private company with a profit motive will do a better job of identifying flaws up front as compared to the government” (Miceli and Sirmans, 1995: 86). 
consistent with these doubts, as established registration systems are not only more effective but also less costly than recording systems in European countries.

Recording suffers a substantial degree of duplication even when a mature title assurance sector develops. First, title plants have to file information on all transactions and relevant facts, not only on the rights being transacted or examined. Consequently, there is less advantage in being able to choose between ex ante or ex post purging. Second, title plants only serve companies' internal administrative functions, as they have no legal effect. This means that the whole chain of title is examined for each transaction. (Marketable title statutes limiting the time required for title searches reduce this cost but may also threaten the security of property rights.) Third, a double duplication of costs takes place in the US system. Private title plants duplicate the information of the public registers. In addition, different title plants hold duplicate information, given that in many areas there is more than one title plant. Some duplication can be avoided with better-organized recording officesmainly, by using a tract index. General automation may also facilitate gathering information from public records and reduce the extent and cost of archive duplication in the near future. It is, however, unlikely to avoid the need for filtering this information or to reduce duplication in repeated examination of old titles.

Potential economies of scope in information production and purging of rights and of register information are also hard to reach under recording. Information on the quality of titles is under-utilized and has to be produced repeatedly. This is also due to the voluntary nature of purging, as in some cases title defects are not removed after being identified by the title report. Furthermore, even when defects are removed, the information on the public records is not simplified accordingly. The public record accumulates information on all 
kinds of rights, defective and clean, dead and alive. ${ }^{20}$ This mix of rights increases the cost of future title searches. Potential savings will be incomplete and will depend on hiring the same expert. Private title plants can simplify their information, but they still face similar problems. ${ }^{21}$

Lastly, with respect to suppliers' incentives, the two main title assurance industries developed under recording of deeds have been heavily regulated. Both in France and the US they have administered pricing, entry barriers and comprehensive rules on products and processes, partly as an end result of incidents of fraud and bankruptcy.22 In particular, as title plants enjoy decreasing unit costs, ${ }^{23}$ suppliers are good candidates for becoming natural monopolies. Understandably, their behavior has been repeatedly scrutinized and sanctioned by competition authorities. ${ }^{24}$

20 This perverse effect may be reduced if the legal system or the interest in inducing demand drives notaries or lawyers to purge all titles before recording the deeds. (See n. 13 above for an example in which lawyers claimed to have performed this role.) Observe, however, that the recording system then loses the previously mentioned advantage of 'insuring over' instead of curing minor title clouds.

${ }^{21}$ Relying on their own old title reports is risky because the law may have changed since the previous examination (Johnson, 1966: 401). In fact, even if a new insurer is retained in a later transaction, it will frequently examine the full chain of title again. These problems are shown by the diversity of practices and proposals regarding reliance on prior examinations (McCormack, 1992: 126) and reissue discounts (Boackle, 1997).

22 See ZERP (2007), for European notaries, Suleiman (1987) for French notaries; and Lipshutz (1994), Nyce and Boyer (1998), Burke (2000, chapters 14 and 15) and Palomar (2000, chapters 15 and 18) for US title insurance.

${ }^{23}$ The costs of building and maintaining title plants are fixed (Lipshutz, 1994: 28) and account for up to half the total costs of title insurance companies (Plotkin, cited by Villani and Simonson, 1982: 274, n. 6).

24 See FDC (1999) for references to two acquisitions which led to consolidation of title plants in several markets. Divestures were required by antitrust authorities later. 
Moreover, registers of rights are not always slow and ineffective bureaucracies.

Countries with registration of rights display a variety of incentive structures and results in terms of, at least apparent, productivity. Some of the most appalling results were produced by registers with standard fixed-salary bureaucracies (Cook County, Puerto Rico, England before 1990). More professional, judicial-style bureaucracies, as in Germany or Scandinavia, seem to produce different outcomes, however, especially when each registrar is compensated with the profits of his or her office. ${ }^{25} \mathrm{~A}$ corporate version of this Ancient Regime predecessor of private franchise management has also been used to set up registration in some developing countries. ${ }^{26}$ This possibility shows that the conversion of private title plants into registers of rights, once defended by Janczyk (1977: 226-27), is not as strange as it might appear.

\section{B. The risk of ineffectual registration}

It is also often believed that registration is more costly but provides more security for property rights, for several reasons. Mainly, registration makes it possible to fully protect good faith acquirers. In principle, the protection granted by recording is intrinsically inferior

25 In this case, a government department manages the relation with a professional network of civil servants. The department regulates entry, processes and prices. Each civil servant then manages an office, recruiting its employees, who are not civil servants and may also be paid with a share of the residual. (A similar hybrid organization was analyzed in Arruñada [1996]). This old arrangement is similar to the one being applied in modern public services reforms. These, however, often have grander plans but weaker incentives, as shown by the paradigmatic 'internal market' and 'fund-holding' doctors introduced by the 1989 reform of the British NHS.

26 A move in this direction was the transformation in 1990 of the English Land Register into a semi-privatized executive agency, with huge productivity improvements (Sparkes, 1999: 18). A similar transformation took place in The Netherlands in 1994 (Jong, 1998). 
in that it is largely contractual in nature so does not take advantage of all the enforcement benefits of property rights. Moreover, as argued above, the protection given to registered right holders by a surviving registration system cannot be detrimental to current right holders. As pointed out by Baird and Jackson, "[i]n a world where information is not perfect, we can protect a later owner's interest fully, or we can protect the earlier owner's interest fully. But we cannot do both” (1984: 300). The assertion is accurate but the assumption is crucial: registration is designed to produce perfect information and thus protect both the earlier and the later owners. ${ }^{27}$ If it fails to protect owners on a significant number of occasions its chances of survival are very limited. ${ }^{28}$ Finally, a registration system that clearly defines property rights may be useful even without proper third-party enforcement, if such clear definition enhances an owner’s loss aversion and “endowment effect,” and this deters seizures. In other words, with badly defined property rights, several parties have endowment effects on the same asset, motivating them to apply force to secure the asset (Mullainathan, 2005).

However, effectiveness is not guaranteed when creating a new register. It is even at risk in functioning registers, because of several systematic but not universal inadequacies.

27 Referring to recording but in a similar vein, Epstein (1987: 18) asserts, “[t]he basic system of recordation is best understood as an institutional response to the structural weaknesses in any common-law resolution of the ostensible ownership problem. Commonlaw solutions attempt to reduce the total loss by assigning it to one party or another. Institutional responses seek to eliminate the loss by a more comprehensive system of social control" (Epstein, 1987: 18, emphases in the original).

28 Some formal models differ from this when assuming that recording (plus title insurance) and registration are on an equal footing with the incidence of claims - that is, the same level of surviving defects. For example, Miceli and Sirmans (1995), Miceli, Sirmans and Turnbull (1998), and Miceli, Sirmans and Turnbull (2000). In contrast, Miceli, Sirmans and Kieyah (2001), and Arruñada and Garoupa (2005) assume unequal incidence. 
Established registers mainly fail to fulfill the promises of registration by being slow and incomplete. Oddly, they also fail by being too effective.

Slowness means that a long time is needed to get registration. Meanwhile, private deeds are given priority conditional to final registration so that, during the 'registration gap,' the register functions as a record of deeds. ${ }^{29}$ The registers of Cook County, England and Puerto Rico saw chronic episodes of registration delay, which resulted in very different outcomes—closure, successful reform, and title insurance and reform, respectively. The lesson is that registration can only function properly with sound incentives. Governments are not always prepared to provide or keep them, however.

Incompleteness of registration is driven by both legal and judicial decisions which lead to enforcement as property—in rem—rights of interests which are not registered. ${ }^{30}$ This causes some difficulty for those 'overriding interests' which are easily observable (such as possessory rights), but poses a more serious problem for abstract overriding interests (such as tacit liens produced by operation of the law, held by employees and governments, for instance). Any proposed solution to the problem comes up against not only legislative barriers but also conveyancers' and judicial opposition. Conveyancers often seek to protect their market: the weaker the effects of registration, the greater the demand for private title assurance services. Registration of rights also constrains the monopoly of the courts in deciding cases. If registration decisions are conclusive, courts cannot allocate property

29 The registration of 'caveats,' giving notice of uncertain outstanding interests, has a similar effect (McCormack, 1992: 91), but only on those titles affected.

${ }^{30}$ Rose summarizes this tendency graphically when she points out the repeated failed attempts at clarifying property law: "legislatures pass new versions of crystalline record 
rights but only contract rights, and this may limit their freedom to decide on the basis of fairness. ${ }^{31}$ It is understandable that courts tend to defend their monopoly when the registers are not part of the court system, which is a common occurrence because malfunctioning of the courts is a main motivation for creating a land register. Even when registers do not err often, judges are only too keen to deny the conclusiveness of registration, thus debasing the system. These problems have been suffered by many registers, not only in the US. This is perhaps why one of the most complete registers, the German Grundbuch, has traditionally been under the responsibility of judges. 32

Finally, governments find it useful to use effective registers as gatekeepers for all kinds of public obligations. ${ }^{33}$ This has always been done by explicitly defining a certain obligation as a property burden. Land taxation is an old example for privacy, recording and registration. ${ }^{34}$ Public use regulation is a more recent case. It is tempting for governments to require even minor obligations to be fulfilled before a right can be registered, implicitly granting them in rem protection. ${ }^{35}$ Taken to extremes, this may lead users to avoid the

systems - only to be overruled later, when courts once again reinstate mud in a different form" (1988: 580). For history and references, see mainly 585-90.

31 As analyzed by Rose (1988, especially pp. 584-85 and 597-601).

32 Something similar can be said about the land court of Massachusetts that is responsible for administering its Torrens register: "Unlike other jurisdictions, the Massachusetts courts have not carved out any additional exceptions to the legal conclusiveness of the certificate of title" (Shick and Plotkin, 1978: 106). Furthermore, the register is relatively complete with, for instance, mandatory registration of boundaries (at 118).

33 See Kraakman (1986) for a theory of legal gatekeeping.

34 Policy reformers in the $18^{\text {th }}$ and $19^{\text {th }}$ centuries were conscious of this issue: their original decisions to place the registers within the realm of the Ministry of Finance (France) or the Ministry of Justice (Germany, Spain) were related to their primary goals of making them an instrument for tax collection and private contracting, respectively.

35 Making information on registers freely available to the public imposes an additional cost on owners, by reducing their privacy and increasing the risk of fraud. It may therefore have 
register. Furthermore, when the obligations are generally perceived as inefficient, there will be a temptation to dilute enforcement instead of changing the law.

\section{The need for adaptation}

The social choice of titling system should also be influenced by the actual demand for title quality. In particular, demand for titling services may vary substantially across countries due to differences in the distribution of land value. Essentially, property titling can be seen as a procedure for defining a set of property rights with a certain degree of precision. The pioneering argument drawn up by Demsetz (1967) is applicable here. It states that economic agents demand greater precision in the definition of rights for the most valuable goods or, in dynamic terms, as goods increase in value.

This argument has been developed in the field of titling by Arruñada and Garoupa (2005). In our model, the value of property rights depends on the probability that claimants with better legal rights may appear. The three legal systems we consider-privacy, and the two public systems of recording of deeds and registers of rights_-are assumed, following widespread experts’ judgment, to increasingly reduce this probability but involve proportionately higher costs.

In our model, once a public titling system is in place, land owners choose to rely on public titling or to keep their rights private. Consequently, the optimum titling system depends on the costs and value of the different systems and on how the value of land is

a similar detrimental effect for registration, aggravated by the power of new technologies to bring together data from many sources. This effect could be reduced by limiting access to the register to those so authorized by owners and those with a legitimate interest. However, 
distributed throughout the economy. In particular, social choice of titling system is given by the net balance of several effects: recording causes under-assurance of higher value land, while registration causes crowding out and over-assurance of lower value land. The net balance of these effects and, therefore, the optimal title system are determined by the relative cost effectiveness and pricing of titling (including private 'title assurance services'). Recording triggers under-assurance of land which is recorded under recording but, given its greater value, would be efficiently registered. Conversely, crowding out happens under registration because its higher price leads owners to keep private some lower-value land which otherwise would have been recorded. Similarly, some mid-value land that would have been recorded under recording is registered under registration, causing over-assurance.

The net balance of such effects and, therefore, the optimum system are determined by the distribution of firms and the effectiveness and relative costs of the different systems, including those of the private assurance services that may act as complements or substitutes of the public titling system. Optimal policy decisions will, therefore, require substantial adaptation to local circumstances.

\section{A quantitative comparison}

Arruñada and Garoupa (2005) conclude that the efficient choice of titling system is an empirical issue that cannot be solved on purely theoretical grounds. ${ }^{36}$ Studies such as those

the public files were wholly open to the public in 28 of the 42 jurisdictions surveyed by the UN-ECE (2000).

${ }^{36}$ A substantial body of empirical literature has examined the effects of land titling on many social and economic variables, such as employment, credit, investment, violence, market beliefs and even health. See, amongst others, Besley (1995), Alston et al. (1996, 1999), 
carried out by the European Mortgage Federation (EMF) put together the type of data suitable for clarifying these matters empirically. ${ }^{37}$ At the price of a small sample size, this data offers two main advantages over alternative studies. First, it measures not only the costs — mainly, time and fees — of titling but also titling benefits, as it estimates two indicators of legal certainty: mortgage repossession time after default and lenders’ operating costs. Second, it considers all standard procedures instead of only those which are formally compulsory. For instance, it computes the cost of retaining professional conveyancers when most transactors do retain them, even if they are not obliged to do so and could prepare the contracts by themselves. ${ }^{38}$ The latter is also a feature of the data developed by the University of Bremen’s Centre of European Law and Politics for the European Commission

Lanjouw and Levy (2002), Field (2004, 2005, 2007), Galiani and Schargrodsky (2004, 2010) and Di Tella, Galiani and Schargrodsky (2007). A recurring problem in most of this literature is the potential influence that hidden causal variables may have on both the titling decision and its supposed consequences. Most of these titling efforts have applied some form of registration, which helps explain why there is little evidence on the differential effects of recording and registration.

37 Mainly EMF (2007), and Low, Sebag-Montefiore and Dübel (2003).

38 They therefore overcome two of the main criticisms raised in Arruñada (2007a) against alternative measures such as the World Bank's Doing Business indicators. In addition, Doing Business data does not distinguish the type of title system in place in each country, which drastically limits its usefulness. E.g., Amin and Haidar (2008) find that, according to the Doing Business data, registering property in civil law countries costs $22 \%$ more. However, they forget that Doing Business computes notary costs but not the lawyer and conveyancing costs typically but not mandatorily incurred in common law countries. The error term in their regression is therefore correlated with their main explanatory variable. Moreover, they implicitly assume that the value provided by titling systems is the same in all countries without considering even the most basic difference-that between recording and registration. (As shown by Arruñada [2003: 416-20], the common versus civil law divide is not correlated with any particular titling system.) Lastly, their measure of total cost includes transaction taxes. Countries with high taxes on land transactions often have lower taxes on land tenure, and this difference should be considered separately when comparing legal systems. 
(ZERP, 2007). It will be used here to compare costs because it surveys a much larger sample of countries.

According to this data, summarized in the attached tables, European registration systems are not only more effective but also less costly than recording systems.

First, as expected, registers of rights exhibit far superior performance as regards the value and quality of registration services. This can be seen in the indicators presented in the first panel of Table 1. Faster and safer registration and repossession are main drivers behind lower prices for mortgages, adjusted for differences in product mix, interest rate risk, credit risk and prepayment risk, so that they represent a comparable price to the borrower; and lower operating costs for mortgage lenders, measured as a percentage of outstanding lending. ${ }^{39}$ The fact that mortgage repossession is faster in countries with registers of rights is fully consistent with the theory, as they are expected to provide better information on current valid rights and their priority. They therefore facilitate calculation of what is owed, establish priority amongst the various mortgages in a reliable way, and avoid litigation over the ownership and capacity of the contracting parties, drastically reducing the number of legal defenses that can be used by the mortgagor after default.

Of course, these observations are open to alternative interpretations. On the one hand, part of the observed differences could be attributed to variables that have been omitted in the analysis, mainly differential court performance. In fact, data in panel $B$ comparing average judicial performance in both samples of countries lends some credit to this explanation. Nevertheless, the differences in judicial performance seem too small to account

39 See Low, Sebag-Montefiore and Dübel (2003: 43-44). 
for the whole difference in repossession time. It is therefore likely that registration improves the mortgage repossession process by providing it with better inputs. On the other hand, the choice between recording and registration could be endogenous, having been influenced by the overall efficiency of the legal system, so that countries with less efficient legal systems should optimally rely on recording rather than registration. European history provides a natural experiment that could refute this argument. The French region of Alsace-Moselle has a land registration system (Livre foncier) because it was part of the German empire between 1870 and $1918 .{ }^{40}$ The system has two key features of registration: it is run by judges who examine the legality of each transaction and the registered rights are presumed valid. Interestingly, French authors consider it safer for users (Piedelièvre, 2000: 20) and advantageous (Simler and Delebecque, 2000: 622).

Second, registers of rights also lead to much lower legal transaction costs than recording of deeds. As shown in panel $A$ of Table 2, the typical home sale with a mortgage loan for $70 \%$ of the home value is $86.47 \%$ costlier in countries with recording of deeds. Only a small part of this difference could be attributable to lower average home values in countries with recording, as shown in panel $B$, which compares across countries the transaction costs of buying homes of three different values. For other analyses, results are likely to differ more, however, given that most countries set ad valorem price schedules, many of which imply cross-subsidies among transactions of different value.

Comparing costs for the average home transaction is a way of summarizing the information and focusing on the transactions which are most relevant in each country. An alternative solution is to measure the transactions costs of the same transaction in all

40 See, e.g., Piedelièvre (2000: 17) and Simler and Delebecque (2000: 620-22). 
countries (let us say, a $€ 100,000$ home) and then dividing such costs by some measure of each country's per capita income (as done, e.g., in Doing Business). Such an exercise is performed in panel $C$, expressing costs in purchasing power standard units of GDP per capita. Results are also very similar to those in panels $A$ and $B$, because countries and average transactions in the sample are relatively similar. However, if we were comparing countries at widely different levels of economic development, this third method could produce unrepresentative results, because the transaction taken as reference may be of little relevance for both the more developed and the less developed countries, a problem compounded when purchasing power differences are neglected.

As expected, the difference in total legal transaction costs is caused by substantially lower conveyancing costs in registration, which are reduced by about half. This result is consistent with the substitution argument between conveyancing and public titling. Results also show lower registration costs for registers of rights but differences here are much less significant.

These comparisons of performances and costs are provided here mainly to show which variables we need to measure in order to examine these institutions empirically. However, even if these results seem relevant, it would be premature to interpret them as causal effects, given the small samples involved. In addition, all countries in these samples are relatively developed, and the relative performance of titling systems could be different in less developed countries. For instance, they may find it harder to avoid a regression of registers of rights to de facto recorders of deeds. 


\section{References}

Alston, Lee J., Gary D. Libecap, and Bernardo Mueller. 1999. Titles, Conflict and Land Use: The Development of Property Rights and Land Reform on the Brazilian Frontier. Ann Arbor, MI: University of Michigan Press. , and Robert Schneider. 1996. "The Determinants and Impact of Property Rights: Land Title on the Brazilian Frontier," 12 Journal of Law, Economics and Organization 25-61.

Amin, Mohammad, and Jamal Ibrahim Haidar. 2008. "The Cost of Registering Property: Does Legal Origin Matter?,” The World Bank, October 20 (http://ssrn.com/abstract=1287217, visited 22 November, 2008).

Anderson, J. Stuart. 1992. Lawyers and the Making of English Land Law, 1832-1940. Oxford: Clarendon Press.

Arruñada, Benito. 1996. “The Economics of Notaries,” 3 European Journal of Law and Economics 5-37. . 2001. "Pasado, presente y futuro del notariado," 2 Folio Real: Revista Peruana de Derecho Registral y Notarial 135-53. . 2002. "A Transaction-Cost View of Title Insurance and its Role in Different Legal Systems," 27 The Geneva Papers of Risk and Insurance 582-601. . 2003. "Property Enforcement as Organized Consent," 19 Journal of Law, Economics, and Organization 401-444. . 2007a. "Pitfalls to Avoid when Measuring the Institutional Environment: Is 'Doing Business’ Damaging Business?” 35 Journal of Comparative Economics 729-47. . 2007b. "Market and Institutional Determinants in the Regulation of Conveyancers," 23 European Journal of Law and Economics 93-116.

In press. Business formalization: Costs versus institutional efficiency

(Formalización de empresas: Costes frente a eficiencia institucional), Cizur Menor: Thomson. and Nuno Garoupa. 2005. "The Choice of Titling System in Land,” 48 Journal of Law and Economics 709-727.

Baird, Douglas G., and Thomas H. Jackson. 1984. "Information, Uncertainty, and the Transfer of Property,” 13 Journal of Legal Studies 299-320.

Besley, Timothy. 1995. "Property Rights and Investment Incentives: Theory and Evidence from Ghana,” 103 Journal of Political Economy 903-37.

Boackle, Kenneth F. 1997. Real Estate Closing Deskbook: A Lawyer's Reference Guide \& State-By-State Summary. Chicago, IL: General Practice, Solo and Small Firm Section, American Bar Association. 
Bostick, C. Dent. 1987. "Land Title Registration: An English Solution to an American Problem,” 63 Indiana Law Journal 55-111.

Buchanan, James M., and Yong J. Yoon. 2000. "Symmetric Tragedies: Commons and Anticommons,” 43 Journal of Law and Economics 1-13.

Burke, D. Barlow. 2000. Law of Title Insurance, $3^{\text {rd }}$ ed. $\left(1^{\text {st }}\right.$ ed., 1986). New York: Aspen Law and Business.

Calabresi, Guido, and A. Douglas Melamed. 1972. "Property Rules, Liability Rules, and Inalienability: One View of the Cathedral,” 85 Harvard Law Review 1089-128.

Cribbet, John E. 1975. Principles of the Law of Property, $2^{\text {nd }}$ ed. Mineola, NY: The Foundation Press.

Demsetz, Harold. 1967. “Toward a Theory of Property Rights,” 57 American Economic Review 347-59.

Di Tella, Rafael, Sebastián Galiani, and Ernesto Schargrodsky. 2007. "The Formation of Beliefs: Evidence from the Allocation of Land Titles to Squatters,” 122 Quarterly Journal of Economics 209-41.

Dukeminier, Jesse, and James E. Krier. 1998. Property, $4^{\text {th }}$ ed. New York: Aspen Law and Business.

EMF, European Mortgage Federation. 2007. Study on the Efficiency of the Mortgage Collateral in the European Union, Brussels: EMF.

Epstein, Richard A. 1987. "Inducement of Breach of Contract as a Problem of Ostensible Ownership,” 16 Journal of Legal Studies 1-41.

FDC, Federal Trade Commission. 1999. Annual Report to Congress. Fiscal Year 1998. Washington DC: Department of Justice Antitrust Division.

Field, Erica, 2004. "Property Rights, Community Public Goods and Household Time Allocation in Urban Squatter Communities,” 45 William and Mary Law Review 837-87. , 2005. "Property Rights and Investment in Urban Slums," 3 Journal of the European Economic Association Papers and Proceedings 279-90. . 2007. "Entitled to Work: Urban Property Rights and Labor Supply in Peru,” 122 Quarterly Journal of Economics 1561-602.

Galiani, Sebastián, and Ernesto Schargrodsky, 2004. “The Health Effects of Land Titling,” 2 Economics and Human Biology 353-72. , and _ 2010. "Property Rights for the Poor: Effects of Land Titling,” 94 Journal of Public Economics 700-29.

Hansmann, Henry, and Reinier Kraakman. 2002. "Property, Contract, and Verification: The Numerus Clausus Problem and the Divisibility of Rights,” 31 Journal of Legal Studies S373-S420.

Heller, Michael A. 1998. "The Tragedy of the Anticommons: Property in the Transition from Marx to Markets,” 111 Harvard Law Review 621-88. . 1999. "The Boundaries of Private Property,” 108 Yale Law Journal 1163-223. , and Rebecca S. Eisenberg. 1998. "Can Patents Deter Innovation? The Anticommons in Biomedical Research,” 280 Science 698-701. 
Janczyk, Joseph T. 1977. “An Economic Analysis of the Land Systems for Transferring Real Property,” 6 Journal of Legal Studies 213-33.

Johnson, Harry M. 1966. “The Nature of Title Insurance,” 33 Journal of Risk and Insurance 393-410.

Jong, Jitske de. 1998. “Access to Geo-information in the Netherlands: A Policy Review,” in J. Zevenbergen, Free Accessibility of Geo-Information in the Netherlands, the United States and the European Community. Delft: Delft University Press.

Kraakman, Reinier H. 1986. "Gatekeepers: The Anatomy of a Third-Party Enforcement Strategy,” 2 Journal of Law, Economics and Organization 53-105.

Lanjouw, Jean, and Philip Levy. 2002. "Untitled: A Study of Formal and Informal Property Rights in Urban Ecuador,” 112 Economic Journal 986-1019.

Levmore, Saul. 1987. "Variety and Uniformity in the Treatment of the Good-Faith Purchaser,” 16 Journal of Legal Studies 43-65.

Lipshutz, Nelson R. 1994. The Regulatory Economics of Title Insurance. Westport, CT: Praeger.

Low, Simon, Matthew Sebag-Montefiore, and Achim Dübel. 2003. Study on the Financial Integration of European Mortgage Markets. Brussels: European Mortgage Federation and Mercer Oliver Wyman.

McCormack, John L. 1992. “Torrens and Recording: Land Title Assurance in the Computer Age,” 18 William Mitchell Law Review 61-129.

McDougal, Myres S., and John W. Brabner-Smith. 1939. "Land Title Transfer: A Regression,” 48 Yale Law Journal 1125-51.

Merrill, Thomas W., and Henry E. Smith. 2000. "Optimal Standardization in the Law of Property: The Numerus Clausus Principle,” 110 Yale Law Journal 1-70. , and __ 2007. Property: Principles and Policies, New York: Foundation Press.

Miceli, Thomas J., and C. F. Sirmans. 1995. "The Economics of Land Transfer and Title Insurance,” 10 Journal of Real Estate Finance and Economics 81-88. , and Joseph Kieyah. 2001. "The Demand for Land Title Registration: Theory with Evidence from Kenya,” 3 American Law and Economics Review 275-87. , and Geoffrey K. Turnbull. 1998. "Title Assurance and Incentives for Efficient Land Use,” 6 European Journal of Law Economics 305-23. , and . 2000. "The Dynamic Effects of Land Title Systems," 47 Journal of Urban Economics 370-89.

Mullainathan, Sendhil. 2005. "Development Economics through the Lens of Psychology,” in F. Bourguignon and B. Pleskovic, eds., Proceedings of the Annual Bank Conference on Development Economics: Lessons of Experience. Washington and New York: The World Bank and Oxford University Press, 45-70.

Nyce, Charles, and M. Martin Boyer. 1998. “An Analysis of the Title Insurance Industry,” 17 Journal of Insurance Regulation 213-56.

Oliver y Esteller, Bienvenido. 1892. Derecho inmobiliario español: Exposición fundamental y sistemática de la Ley Hipotecaria, vol. 1. Madrid: Sucesores de Rivadeneyra. 
Palomar, Joyce D. 1999. "The War Between Attorneys and Lay Conveyancers-Empirical Evidence Says 'Cease Fire!',” 31 Connecticut Law Review 423-546. 6, 2000). . 2000. Title Insurance Law. St. Paul, MN: West. (First ed., 1994. Last revised: July

Picod, Yves. 1999. Sûretés: Publicité foncière, $7^{\text {th }}$ ed., in H. Mazeaud, L. Mazeaud, J. Mazeaud and F. Chabas, eds., Leçons de Droit Civil, tome 3, vol. 1. Paris: Montchrestien.

Piedelièvre, Stéphane. 2000. Real Property Publicity (La publicité foncière). Paris: Librairie Général de Droit et Jurisprudence.

Powell, Richard R. B. 1938. Registration of the Title to Land in the State of New York. Rochester, NY: Lawyers Co-Operative Publishing Company.

Raucent, León. 1998. Fonction et statuts des notaires, $10^{\text {th }}$ ed. Louvain: Académia-Bruylant. Rose, Carol M. 1988. "Crystals and Mud in Property Law," 40 Stanford Law Review 577610.

Shick, Blair C., and Irving H. Plotkin. 1978. Torrens in the United States: A Legal and Economic Analysis of American Land Registration Systems. Lexington, CT: Heath.

Simler, Philippe, and Philippe Delebecque. 2000. Private Law: Securities, Real Property Publicity (Droit Civil: Les sûretés, la publicité foncière), $3^{\text {rd }}$ ed. Paris: Dalloz.

Sparkes, Peter. 1999. A New Land Law. Oxford and Portland: Hart Publishing.

Suleiman, Ezra N. 1987. Private Power and Centralization in France: The Notaries and the State. Princeton, NJ: Princeton University Press.

Troister, Sidney H., and Kathleen A. Waters. 1996. "Real Estate Conveyancing in Ontario: A Nineties Perspective,” mimeo. Toronto: Lawyers' Professional Indemnity Company.

UN-ECE (United Nations Economic Commission for Europe). 2000. Study on Key Aspects of Land Registration and Cadastral Legislation. London: Her Majesty Land Register.

Villani, Kevin, and John Simonson. 1982. "Real Estate Settlement Pricing: A Theoretical Framework," 10 American Real Estate and Urban Economics Association Journal 24975.

Whalan, Douglas J. 1982. The Torrens System in Australia. Sidney: Law Book Company. Willman, Raymond, and Jean-François Pillebout. 2002. Buying or Selling a Home: The Notary's Mission, $3^{\text {rd }}$ ed. Paris: Mémos de Conseils par des Notaires.

World Bank. 2003-2009. Doing Business. Washington DC: World Bank.

ZERP. 2007. Conveyancing Services Market (Study COMP/2006/D3/003, Final Report). Brussels: Centre of European Law and Politics, University of Bremen (ZERP). 
Table 1. Performance indicators of eight developed titling systems

(simple averages for two samples of EU countries with different titling systems)

\begin{tabular}{ccc}
\hline $\begin{array}{c}\text { Recording of } \\
\text { deeds }\end{array}$ & $\begin{array}{c}\text { Registration } \\
\text { of rights }\end{array}$ & Ratio \\
{$[1]^{\mathrm{a}}$} & {$[2]^{\mathrm{a}}$} & {$[1] /[2]$} \\
\hline
\end{tabular}

A. Performance indicators of titling systems:
Mortgage adjusted price ${ }^{\mathrm{b}, \mathrm{c}}$
$1.04 \%$
$0.93 \%$
$111.56 \%$
Operating cost of mortgage provision for lenders, as a \% of outstanding lending ${ }^{\mathrm{C}}$
$0.59 \%$
$0.39 \%$
$150.64 \%$
Mortgage registration time, in days ${ }^{\mathrm{d}}$
37.19
13.40
$277.50 \%$
Mortgage repossession time, in months ${ }^{\mathrm{e}}$
37.03
9.25
$400.36 \%$

\section{B. Performance indicators of judicial} systems. Judicial enforcement of a contractual dispute related to a sale of goods: ${ }^{\mathrm{f}}$

Number of procedures 32.50 32.25 $97.74 \%$

Days from when the plaintiff files the lawsuit until actual payment

Cost, in \% of claim

658.00

423.25

$155.46 \%$

21.48

19.58

$109.71 \%$

Notes: ${ }^{a}$ Classification of titling systems and from UN-ECE (2000). Registration countries are Denmark, Germany, Spain and the UK; while recording countries are France, Italy, Portugal and The Netherlands. ${ }^{\mathrm{b}}$ Adjusted mortgage prices are based on a composite of prices for all lenders and are adjusted for differences in product mix, interest rate risk, credit risk and prepayment risk, so that they represent a comparable price to the borrower. ${ }^{\text {C }}$ Data for 2003 from Low, Sebag-Montefiore and Dübel (2003: 34). ${ }^{\mathrm{d}}$ Data for 2006 from EMF (2007: 11). ${ }^{\mathrm{e}}$ Data for 2006 from EMF (2007: 174-91). ${ }^{\mathrm{f}}$ Data for 2007 from the Doing Business 2009 survey (World Bank, 2008). Averages drawn up by the author. 
Table 2. Transaction legal costs (simple averages for samples of $20 \mathrm{EU}$ countries with different titling systems)

$\begin{array}{ccc}\begin{array}{c}\text { Recording of } \\ \text { deeds }\end{array} & \begin{array}{c}\text { Registration } \\ \text { of rights }\end{array} & \text { Ratio } \\ {[1]^{\mathrm{a}}} & {[2]^{\mathrm{a}}} & {[1] /[2]}\end{array}$

A. For the average home in each country, as a percentage of home value:

Solicitors' or notary fees ${ }^{b}$

$\begin{array}{lll}1.48 \% & 0.69 \% & 214.72 \% \\ 0.30 \% & 0.26 \% & 112.67 \% \\ 1.78 \% & 0.95 \% & 186.47 \%\end{array}$

Total legal costs

$1.78 \%$

$0.95 \%$

$186.47 \%$

Average home value $(€)$

150,737

164,724

$91.51 \%$

B. For homes of different representative values, as a percentage of home value:

For a $€ 100,000$ home:

Solicitors' or notary fees ${ }^{b}$

Property and mortgage registration ${ }^{c}$

Total legal costs

$\begin{array}{lll}1.74 \% & 0.94 \% & 185.50 \% \\ 0.32 \% & 0.31 \% & 103.79 \% \\ 2.07 \% & 1.25 \% & 165.23 \%\end{array}$

For a $€ 250,000$ home:

Solicitors' or notary fees ${ }^{b}$

$1.19 \%$

$0.26 \%$

$0.51 \%$

$234.43 \%$

Property and mortgage registration ${ }^{c}$

$1.45 \%$

$0.24 \%$

$109.71 \%$

Total legal costs

$0.75 \%$

$194.33 \%$

For a $€ 500,000$ home:

Solicitors' or notary fees ${ }^{b}$

$0.93 \%$

$0.35 \%$

$268.72 \%$

Property and mortgage registration ${ }^{\mathrm{c}}$

$0.24 \%$

$0.21 \%$

$111.41 \%$

Total legal costs

$1.17 \%$

$0.56 \%$

$208.65 \%$

C. For a $€ 100,000$ home, measured in terms of the GDP per capita of each country in purchasing power standards $(E U-27=100):^{d}$

$\begin{array}{llll}\text { Solicitors' or notary fees }{ }^{\mathrm{b}} & 1,914.30 & 958.05 & 199.81 \% \\ \text { Property and mortgage registration }^{\mathrm{c}} & 340.31 & 266.78 & 127.57 \% \\ \text { Total legal costs } & 2,254.61 & 1,224.83 & 184.08 \%\end{array}$

Notes: Data for 2007 from ZERP (2007). ${ }^{a}$ Classification of titling systems from UN-ECE (2000). Registration countries are Austria, The Czech Republic, Denmark, England, Finland, Germany, Ireland, Poland, Scotland, Slovakia, Slovenia, Spain and Sweden; while recording countries are Belgium, France, Greece, Hungary, Italy, Portugal and The Netherlands. ${ }^{b}$ Solicitors' or notary fees, as well as legal fees charged by real estate agents in Denmark and Sweden. ${ }^{\mathrm{c}}$ The transaction includes a mortgage loan for $70 \%$ of the value. Denmark's data were corrected to exclude transaction taxes. Averages drawn up by the author. ${ }^{\mathrm{d}}$ Data for 2007. Source of GDP data: Eurostat. 